\title{
Gastrointestinal Endoscopy Practice in Pandemic Conditions
}

\author{
Pandemi Koşullarında Gastrointestinal Endoskopi Pratiği \\ Sencan Acar, Mustafa Sadecolak, Mukaddes Tozlu, Ahmet Tarik Eminler \\ Department of Gastroenterology, Sakarya University Faculty of Medicine, Sakarya \\ Yazıșma Adresi / Correspondence: \\ Sencan Acar \\ Sakarya University Faculty of Medicine, Korucuk campuss, Endoscopy unit 54040 Korucuk/Adapazarı, Sakarya \\ $\mathrm{T}$ : $+905337697196 \quad$ E-mail : sencanacar@yahoo.com \\ Geliş Tarihi / Received : 12.03.2021 Kabul Tarihi / Accepte: 04.12.2021 \\ Orcid : \\ Sencan Acar https://orcid.org/0000-0001-8086-0956 \\ Mustafa Sadecolak https://orcid.org/0000-0003-3443-1987 \\ Mukaddes TOZLU https://orcid.org/0000-0002-8534-8027 \\ Ahmet Tarik Eminler https://orcid.org/0000-0003-1402-5682 \\ ( Sakarya Tip Dergisi / Sakarya Med J 2021, 11(4):772-780 ) DOI: 10.31832/smj.895992
}

\footnotetext{
Abstract

Objective A novel coronavirus, which is termed COVID-19 or SARS-CoV-2, was declared a pandemic by the WHO since March 2020. Endoscopy is a potential route for infection. Because of this reason, gastroenterology associations around the world recommended the suspension of non-emergency endoscopy. The aim of our study was to investigate the characteristics of the emergency endoscopic procedures performed during the pandemic period and compare with the same period of the previous year.

Materials Our endoscopy unit is the only center in the city where emergency endoscopic intervention and therapeutic endoscopic procedures are performed on adult patients. Only and Methods emergency and urgent endoscopic procedures performed between March 16 and May 18, the period when the pandemic was most intense, were evaluated. The staff in the endoscopy room used full personal protective equipment all endoscopic procedures irrespective of whether or not to test for COVID-19.

Results 96 upper endoscopic ( 56 of them GI bleeding), 26 lower endoscopic (14 of them GI bleeding, mostly malignancy) and 27 ERCP procedures were carried out. Only one patient that 62 years old male, with a negative typical symptom query, was detected PCR positive for COVID-19 on the same day after the procedure. In the same period in 2019, we had performed 98 upper and 25 lower endoscopies and 99 ERCP for emergency indications.

Conclusion COVID-19 pandemic process caused extreme changes in endoscopy procedure practice and also indications. All endoscopy units should always be accoutered for the management of emergency endoscopy procedures such as gastrointestinal bleeding.

Keywords pandemic; endoscopy; hemorrhage

Öz

Amaç COVID-19 veya SARS-COV-2 olarak adlandırılan bir yeni Coronavirüs, 2020 yllının Mart ayından bu yana DSÖ tarafindan pandemi ilan edildi. Endoskopi de bu enfeksiyon için potansiyel bir yoldur. Bu nedenle, dünyadaki gastroenteroloji dernekleri, acil olmayan endoskopinin durdurulmasın önerdi. Çalışmamızın amacı, pandemi dönemde gerçekleştirilen acil endoskopik prosedürlerin özelliklerini araştırmak ve önceki yllın aynt dönemiyle karşılaştırmaktı.

Gereçve Endoskopi ünitemiz, acil endoskopik müdahalenin ve terapötik endoskopik prosedürlerin yetişkin hastalarda yapıldı̆̆ı șhirdeki tek merkezdir. Sadece 16 Mart-18 Mayıs arasında, salgının en Yöntemle yoğun olduğu dönemindeki acil endoskopik prosedürler değerlendirildi. Endoskopi odasindaki personel, COVID-19 için test edilip edilmemesine bakılmaksızın, tüm endoskopik prosedürleri tam kişisel koruyucu ekipman kullandr.

Bulgular Toplamda 96 üst endoskopik (56'smin 56 'sl GIS kanama nedenli), 26 alt endoskopik (14 tanesi GIS kanama nedenli, çoğunlukla malignite) ve 27 ERCP prosedürü yapıldd. Sadece 62 yaşındaki tipik semptom sorgulaması negatif olan bir hastada prosedürden sonra ayn gün COVID-19 için alınmıs olan PCR pozitif olarak tespit edildi. $2019^{\prime} d a k i$ aynı dönemde toplamda 98 üst ve 25 alt endoskopi ile 99 ERCP acil endikasyonlu olarak yapılmıșt.

Sonuç Covid-19 pandemisi, endoskopi işlemlerinde kıstllanmış endikasyonlara neden olmuştur. Tüm endoskopi birimleri her zaman gastrointestinal kanama için acil endoskopi prosedürlerinin yönetimi için uygun olmalıdır. 


\section{INTRODUCTION}

A novel coronavirus termed SARS-CoV-2 emerged from a suspected zoonotic source in Wuhan, China in late December 2019. ${ }^{1}$ On 11 February 2020, World Health Organization (WHO) announced a name for the new coronavirus disease as COVID-19. Driven by its ability to spread through respiratory droplets, including by asymptomatic individuals, COVID-19 has rapidly traversed international borders to infect over 6 million people in over 200 countries. ${ }^{2}$ Turkey reported its first native case of COVID-19 virus infection on March 11, 2020 and also COVID-19 was declared a pandemic by the World Health Organization on same day. ${ }^{3}$ As of May 31st the cases of COVID-19 have been rising exponentially up to 163.942 people infected and 4540 deaths in our country. ${ }^{4}$ The majority arising from İstanbul (60\%), İzmir (6\%) and Ankara (5\%).

All endoscopic procedures should be considered aerosol-generating procedures (AGP). The virus characteristics and its transmission routes make endoscopy a potential route for infection. Possible routes of COVID-19 virus transmission include: person-to-person, respiratory droplets, aerosols generated during endoscopy, and contact with contaminated surroundings and body fluids. Restrictive measures have been implemented worldwide to prevent the spread of COVID-19. Based on these steps, gastroenterology associations around the world recommended the suspension of non-emergency endoscopy. ${ }^{5,6}$ This measure is aimed at reducing the risk of spreading infection from asymptomatic patients, reducing the risk of cross-infection among patients, reducing use of PPE, and reducing unnecessary admissions to hospital resources. ${ }^{7}$

The aim of our study was to investigate the characteristics of the emergency endoscopic procedures performed during the pandemic period and compare with the same period of the previous year.

\section{MATERIAL and METHODS \\ Study Population}

The patients who underwent an emergency or urgent endoscopic procedure within two months including March 16 and May 18, when the procedures were delayed due to a pandemic, were constituted the study group. Along with the demographic characteristics of the patients, the properties and outcomes of the procedures were retrospectively analyzed. In addition, the results obtained in this period were compared with those in the same period of the previous year. The study is cross-sectional type descriptive study.

\section{Changes in Endoscopy Unit Practice}

Due to the pandemic course of the virus in Sakarya (over 1.000.000 population and the 7th city with the highest number of COVID-19 patients in Turkey) the Sakarya University Hospital (750 beds) was fully devoted to the treatment of patients with COVID-19. Since then, routine activity has changed substantially; the need of Intensive Care Units (ICU) and Infectious Disease (ID) beds necessitated repurposing most of the operating rooms, wards, and patient suites to COVID-19 care. All physicians and surgeons switched their daily tasks to become temporary ICU and ID specialists.

Our endoscopy unit is the only center in the city where emergency endoscopic intervention and therapeutic endoscopic procedures (ERCP, stent, dilatation etc.) are performed. It is 600 square meters in size and has 5 routine and one therapeutic endoscopy room. In addition, in accordance with the 1.5 meter distance rule, there is a large observation room where patients can be followed. The fact that our unit was located in a different location from the main hospital, where active infected patients admitted, was advantageous in terms of contamination risk. All (totally six) expert endoscopists and four of seven experienced nurses in our endoscopy unit also played an active role in pandemic course. All elective procedures were postponed in accordance with the measures taken by 
the Ministry of Health at March 16th 2020. Endoscopy is limited to emergency or urgent procedures including the treatment of Gastrointestinal (GI) bleeding, foreign body removal, acute luminal obstruction, post-operative leak and cholangitis. Furthermore, care (initial diagnosis, biopsy, staging, palliation of biliary and luminal obstruction) of cancer patients may also be considered urgent. All endoscopy indications were determined by expert endoscopists. Therefore, we applied case-by-case judgment based on the expertise and endoscopic resources of our center. And also we performed Percutaneous Endoscopic Gastrostomy (PEG) for the patients which the oral feeding are not possible.

\section{Triage and assess risk of patients for COVID-19 before endoscopy}

Before arrival at endoscopy center all patients were asked for the following informations.: (i) fever of more than $37.5^{\circ}$ C, (ii) cough, sore throat or respiratory problem (iii) travel history, (iv) contact history. Any of the positive criteria for these features should be regarded as a clinically suspected case, and COVID-19 testing should be conducted before any endoscopic procedure. For all suspected, probable or confirmed cases, the clinical indication for endoscopy should be reviewed, and only those with emergency or life-threatening conditions should receive endoscopy. While waiting in the entry room before endoscopy, 1.5 meters distance rule was provided between the persons. To help meet this requirement, we only allow 1 family member/chaperone per patient who waits in a centralized waiting area, and this visitor cannot enter the pre- or post-procedure areas. All patients and the attendants wore a mask while in endoscopy unit. Pens, clipboards, phones, and chairs should not be shared. If unsure, these items should be cleaned before use and hand hygiene performed after use. Deep cleaning of the entire endoscopy unit is recommended nightly.

\section{During the endoscopy procedure}

All endoscopy procedures were performed by experienced endoscopists. The staff in the endoscopy room used full personnel protective equipment (PPE) all endoscopic procedures irrespective of whether or not to test for COVID-19. Although we asked the symptoms and test all the suspicious patients, we prefer to take precautions due to the presence of people who may be in the process of asymptomatic and/or incubation period.

Proper donning and doffing practices were followed. ${ }^{8}$ Removing dirty gloves first and performing proper hand hygiene is the most important steps after the procedure. We also paid attention to wear clean gloves before later taking off the face shield and N95 without touching the front of either.

We cared about not to have anybody other than the personnel to be involved in the endoscopy room during the procedure. We have stopped using fellows to perform procedures with certain exceptions to preserve PPE, minimize exposure, and reduce procedure times. The students together with trainees and other caregivers were not allowed to access the procedure room. We have been mindful about minimizing the number of providers in the endoscopy unit at one time and so we have adjusted the number of physicians in the endoscopy unit to be a one person every day. Off-duty workers should stay at home as much as possible. Because of the few procedure rooms in current use, our extra nursing staff have been deployed to other areas of great need in the hospital. Before leaving from work, providers should remove scrubs and wear regular clothes outside the hospital.

The procedure rooms were cleaned and disinfected in detail after each procedure and were ventilated for at least 30 minutes between the procedures. Special attention was paid to the surfaces where any biofilm might hold viral particles.

\section{Outcomes}

The primary outcome of the study is to reveal the indica- 
tions of emergency endoscopic procedures performed in the pandemic period. Secondary outcomes included the features, therapeutic interventions and success rate of the procedures. Also, we aimed to reveal the differences of the results between pandemic and non-pandemic (last year) period.

\section{Statistical analysis}

The statistical analysis program SPSS statistical package (version 24.0; SPSS, Chicago, IL, USA) was used for all statistical analyses. Data for continuous variables are presented as mean \pm SD or as median and range, and data for categorical variables as frequency and percentage. Categorical variables were tested by the chi-square test or the Fisher exact test. Differences in parameters between patients were calculated using the nonparametric Mann- Whitney U test for continuous variables. $\mathrm{p}$ value $<.05$ was considered statistically significant. This study was approved by Sakarya University Clinical Research Ethics Committee, May 20, 2020 / E.4594 and its protocol conforms to the ethical guidelines of the 1975 Declaration of Helsinki as reflected in a priori approval by the institution's Human Research Committee.

\section{RESULTS}

Totally 544 elective endoscopic procedures (358 gastroscopy and 186 colonoscopy), given an appointment before, were postponed on March 16th 2020. After 18 May, these patients were tried to be reached by phone and their appointments were rearranged.

From March 16 to May 18, 2020; 96 ( $62.1 \pm 15.6$ years; 60 men $(61.9 \%)$ emergency or urgent upper endoscopic procedures on adult patients were carried out. 52 (54.1\%) of upper endoscopies performed for emergency indications mostly (37/52, 71.2 \%) for gastrointestinal bleeding (Table-1). The most common diagnosis of gastrointestinal bleeding was peptic ulcer $(14 / 37,38 \%)$. Totally 20 therapeutic procedures were performed for the patients that undergoing emergency endoscopy (5 band ligation for esophageal variceal bleeding, 6 bougie/balloon dilatation for esophageal stricture, 4 stent placement for malignant stricture, 3 for ulcer bleeding, 2 large balloon dilatation for achalasia and 1 foreign body removal). Also 3 endoscopically feeding tube replacement were performed in the same period. The most common indication was severe epigastric pain $(22 / 44,50 \%)$ and suspicion of malignancy (19/44, 43.2\%) among the remaining patients who underwent endoscopy during this period. Malignant lesion was detected in 8 of 19 patients who underwent endoscopy for the suspicion of malignancy.

Twenty-six (59.5 \pm 14.1 years; 19 men $(73.1 \%)$ emergency or urgent lower endoscopic procedures on adult patients were carried out in the pandemic period (Table-2). 14 (53.8 $\%)$ of lower endoscopies performed for emergency indication for gastrointestinal bleeding. The most common diagnosis of gastrointestinal bleeding was malignancy (7/14, $50 \%)$. The indication was suspicion of malignancy among the remaining patients who underwent endoscopy during this period. The procedure could not be completed due to insufficient cleaning in 6/26 (23.1\%) patients.

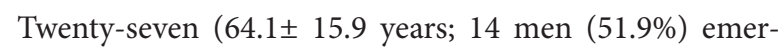
gency or urgent ERCP procedures on adult patients were carried out in this period (Table-3). The most common indication of the patients was symptomatic common bile duct stone $(12 / 27,44 \%)$. Successful stone extraction was achieved in 10/12 (83.3\%) patients. ERCP was performed urgently for five patients because of the cholangitis. Common bile duct stone was the diagnosis of 3 of these patients and one was malignant and the other was benign distal bile duct stricture. Cannulation success could not be achieved in a total of two procedures because of the gastric outlet obstruction. 
Sakarya Med J 2021;11(4):772-780

ACAR et al., : Emergency Endoscopy Indications in Pandemics

\begin{tabular}{|c|c|c|c|c|c|c|c|}
\hline \multirow[t]{2}{*}{ Diagnosis } & \multicolumn{4}{|c|}{ Indication (Emergency) (n:52) } & \multicolumn{3}{|c|}{ Indication (Others) (n:44) } \\
\hline & $\begin{array}{c}\text { Gastro-intesti- } \\
\text { nal Bleeding } \\
(\mathrm{n}: 37 / 71.1 \%)\end{array}$ & $\begin{array}{l}\text { Dysphagia } \\
\text { (n:13/25\%) }\end{array}$ & $\begin{array}{l}\text { Gastric outlet } \\
\text { obstruction } \\
\text { (n:1/2\%) }\end{array}$ & $\begin{array}{c}\text { Foreign Body } \\
\text { removal } \\
(n: 1 / 2 \%)\end{array}$ & $\begin{array}{l}\text { Epigastric Pain } \\
\text { (n:22/50\%) }\end{array}$ & $\begin{array}{l}\text { Suspicion of } \\
\text { malignancy } \\
(\mathrm{n}: 19 / 43.1 \%)\end{array}$ & $\begin{array}{c}\text { Percutenous } \\
\text { Endoscopic } \\
\text { Gastrostomy } \\
\text { (n:3/6.8\%) }\end{array}$ \\
\hline $\begin{array}{l}\text { Peptic ulcer } \\
(\mathrm{n} / \%)\end{array}$ & $14(37.8 \%)$ & - & - & - & - & - & - \\
\hline $\begin{array}{l}\text { Malignancy } \\
(\mathrm{n} / \%)\end{array}$ & $3(8.1 \%)$ & $5(38.4 \%)$ & $1(100 \%)$ & - & - & $8(42.1 \%)$ & - \\
\hline $\begin{array}{l}\text { Esophage- } \\
\text { al variceal } \\
\text { bleeding } \\
(\mathrm{n} / \%)\end{array}$ & $8(21.6 \%)$ & - & - & - & - & - & - \\
\hline $\begin{array}{l}\text { Esophageal } \\
\text { stricture } \\
(\mathrm{n} / \%)\end{array}$ & - & $6(46.1 \%)$ & - & - & - & - & - \\
\hline $\begin{array}{l}\text { Achalasia } \\
(\mathrm{n} / \%)\end{array}$ & - & $2(15.3 \%)$ & - & - & - & - & - \\
\hline $\begin{array}{l}\text { Erozive } \\
\text { gastritis, } \\
\text { Mallory weiss } \\
\text { syndrome,etc } \\
(\mathrm{n} / \%)\end{array}$ & $\begin{array}{c}12 \\
(32.4 \%)\end{array}$ & - & - & - & - & - & - \\
\hline $\begin{array}{l}\text { Other (Gast- } \\
\text { iritis, Hiatal } \\
\text { hernia, etc) } \\
(\mathrm{n} / \%)\end{array}$ & - & - & - & $1(100 \%)$ & $22(100 \%)$ & $11(57.8 \%)$ & $3(100 \%)$ \\
\hline
\end{tabular}

Table-2 The indications and diagnosis of the emergency lower endoscopic procedures on adult patients

\begin{tabular}{|l|c|c|}
\hline Diagnosis & \multicolumn{2}{|c|}{ Indication (n:26) } \\
\hline & $\begin{array}{c}\text { Gastrointestinal } \\
\text { Bleeding } \\
\text { (n:14/53.8\%) }\end{array}$ & $\begin{array}{c}\text { Suspicion of } \\
\text { malignancy } \\
(\mathrm{n}: 12 / 46.1 \%)\end{array}$ \\
\hline Malignancy (n/\%) & $7(50 \%)$ & $2(16.6 \%)$ \\
\hline Polyp (n/\%) & $3(21.4 \%)$ & $4(33.3 \%)$ \\
\hline Diverticulosis (n/\%) & $3(21.4 \%)$ & - \\
\hline Ischemic colitis (n/\%) & $1(7.1 \%)$ & - \\
\hline Incomplete procedure (n/\%) & - & $6(50 \%)$ \\
\hline
\end{tabular}

In addition, we aimed to evaluate the characteristics of emergency endoscopic data performed in this extreme period with the data obtained in the same date range in 2019 (Figure-1). We had performed 98 upper endoscopies for emergency indications mostly $(69 / 98,70.4 \%)$ for gastrointestinal bleeding in the previous year. The most common diagnosis was peptic ulcer $(39 / 69,56 \%)$ as expected. These findings were similar when compared with the pandemic period ( $p>0.05$ ). Twenty-five lower endoscopies were performed in the same period in 2019 with the emergency indication of gastrointestinal bleeding in all of them. The most common diagnosis was diverticulosis $(7 / 25,28 \%)$ for lower gastrointestinal bleeding. The number of the ERCP procedures of the last year was 99, and the most common indication was symptomatic common bile duct stone as well. The unsuccessful cannulation rate was 3/99 (3\%) in this period.

Only one patient that 58 years old male, with a negative typical symptom query, was detected PCR positive for COVID-19 on the same day after the procedure. The test was performed due to the suspicion obtained as a result of the unexplained complaints of fatigue and nausea. The patient was referred to the relevant department. The staff of the endoscopy department that had been in the endoscopy room at that day were monitored for symptoms for 
Sakarya Med J 2021;11(4):772-780

ACAR et al., : Emergency Endoscopy Indications in Pandemics

\begin{tabular}{|c|c|c|c|c|c|}
\hline \multirow[t]{2}{*}{ Diagnosis } & \multicolumn{5}{|c|}{ Indication (n:27) } \\
\hline & $\begin{array}{c}\text { Suspicion of } \\
\text { common bile duct } \\
\text { stone (n:12/44.4\%) }\end{array}$ & $\begin{array}{l}\text { Jaundice } \\
(\mathrm{n}: 6 / 22.2 \%)\end{array}$ & $\begin{array}{l}\text { Cholangitis } \\
\text { (n:5/18.5\%) }\end{array}$ & $\begin{array}{l}\text { Suspicion post- } \\
\text { cholecystectomy } \\
\text { leak } \\
(\mathrm{n}: 2 / 7.4 \%)\end{array}$ & $\begin{array}{l}\text { Biliary stricture } \\
\text { (Follow-up } \\
\text { procedure) } \\
\text { (n:2/7.4\%) }\end{array}$ \\
\hline Common bile duct stone (n/\%) & $9(75 \%)$ & $1(16.6 \%)$ & $3(60 \%)$ & - & - \\
\hline $\begin{array}{l}\text { Malignant distal bile duct stricture } \\
(\mathrm{n} / \%)\end{array}$ & - & $4(66.6 \%)$ & $1(20 \%)$ & - & - \\
\hline Benign distal bile duct stricture (n/\%) & - & - & $1(20 \%)$ & - & - \\
\hline $\begin{array}{l}\text { Ectopic opening of the common bile } \\
\text { duct in the duodenal bulb (n/\%) }\end{array}$ & $2(16.6 \%)$ & - & - & - & - \\
\hline Post- cholecystectomy injury (n/\%) & - & - & - & 2/100\%) & - \\
\hline $\begin{array}{l}\text { Living donor liver transplantation } \\
(\mathrm{n} / \%)\end{array}$ & - & - & - & - & $1(50 \%)$ \\
\hline Hepaticojejunostomy (n/\%) & - & - & - & - & $1(50 \%)$ \\
\hline Unsuccesful cannulation (n/\%) & $1(8.3 \%)$ & $1(16.6 \%)$ & - & - & - \\
\hline
\end{tabular}

48 hours and PCR tests that were administered at 3rd day were detected negative for all of them.

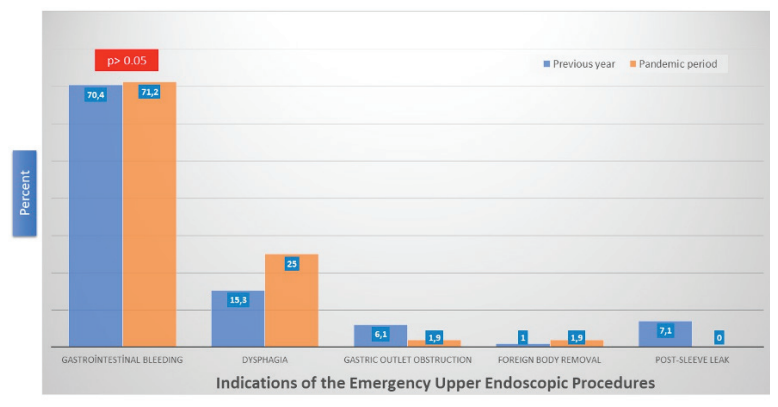

Figure-1. Indications of the emergency upper endoscopic procedures.

\section{DISCUSSION}

We reported that emergency endoscopies could be performed effectively in appropriate patients during the COVID-19 pandemic in this study. We have shown that despite the overload in hospitals due to COVID-19 patients, the emergency endoscopy capacity can be tolerated, especially in terms of GI bleeding. Therefore, it can be concluded that emergency procedures such as GI bleeding, which is the main component of the definition of emergency endoscopy, cannot be postponed independently from other factors such as natural disasters or pandemics.
Endoscopy suites are a conglomeration of endoscopists, nursing staff, technicians, anesthesia providers, and multiple types of equipment. As known, peak viral load is detected in the pre-symptomatic phase of COVID-19 disease, and there are concerns that upper GI procedures including gastroscopy, ERCP, and Endoscopic Ultrasound (EUS) may aerosolize virus particles that are shed from the nasopharynx of infected individuals. ${ }^{9}$ With the detection of live COVID-19 virus in stool in approximately $23 \%$ of the patients, although the viral loads were less than those of respiratory samples, it has been concluded that colonoscopy can also be a transmission route. ${ }^{10}$ Additionally, as microbial spreading can be 1.5-2 meters from a patient undergoing endoscopy, body fluids can splash and there is a risk of environmental transmission when manipulating devices in and out of the working channel of the endoscope. Besides, the contamination has also been observed on endoscopy suite walls and post-op areas and this risk is extented to clerical and cleaning staff in the endoscopy unit. ${ }^{11,12}$ Therefore, in order to minimize the risk of contamination of the health worker, which is $20 \%$ in some countries, it has become necessary to take some measures. $^{13}$

Owing to General Health Insurance system implemented 
in Turkey urgent interventions are made free of charge for all persons, without discrimination. During the pandemic period, testing and treatment costs related to COVID-19 were fully covered by the government also. With the proposal of the Ministry of Health of Turkey to prevent individuals from entering the hospital environment and thus reduce both workload and transmission risk, admissions to the hospital were blocked in all over the country except for emergencies. As expected, the drop in the number of hospitalized patients was in line with the increasing trend in the number of infected cases and related deaths in the country, suggesting that patients did not apply to endoscopy units, except in non-emergency situations.

COVID-19 risk classification for patients admitted for endoscopy are among the measures that can be implented. ${ }^{14}$ This approach was preferred since the early phase of the pandemic. But also there is potential for asymptomatic individuals to be overlooked. Some centers presented the laboratory-based RT-PCR test approach to assess the risk of the pre-endoscopy patients. ${ }^{15}$ But this was time-consuming process and not practical especially for emergency endoscopic procedures. In addition, it should be noted that these approaches are insufficient in rationalizing the use of PPE.

An overview of recommendations by 21 endoscopic associations for performance of an endoscopic procedure during this COVID-19 pandemic is available by Castro Filho et al. ${ }^{16}$ The authors reported that a total of $95 \%$ of the associations recommended temporarily postponing elective/nonurgent procedures; $86 \%$ to stratify patients for risk of COVID-19 before the examination (questionnaire of symptoms and/or patient's body temperature); $38 \%$ to reduce the number of people who accompany patients; $33 \%$ to stimulate self-surveillance of signs/symptoms by Healthcare Workers, and 19\% to contact patients 14 days after the examination to check symptoms. And also they pointed out that all societies recommended the use of personal protective equipment (PPE) during the examination (gloves, mask, goggles, or face shield, gown, and hairnet; double gloves and use of N95 or FFP2/3 masks were recommended in highly suspected or confirmed cases), and $43 \%$ of the associations recommended that the endoscopy team must be trained in wearing and removing PPE. Although, while significant improvements were obtained in the experience of using PPE, a number of new equipment was introduced during the upper GIS endoscopy in this period, to prevent air droplet transmission from the patient. $^{17,18}$

Gastrointestinal bleeding is a medical emergency that results in substantial morbidity, mortality, and health care cost. ${ }^{19}$ It is proven that early endoscopic intervention within 12-24 h of presentation dramatically improves patient outcomes. ${ }^{20}$ The endoscopy is important in revealing the etiology of upper GI bleeding and also performing some interventional procedures. Many associations have always stated GI bleeding in the first place among the emergency endoscopy indications that should be performed also during the pandemic process. ${ }^{21,22}$ Among the emergency endoscopies performed in a study conducted in Italy, GI bleeding indication was reported as $76 \%{ }^{23}$ This proposition is compatible with our results that nearly one-third of our emergency procedures were due to GI bleeding.

Our study has some limitations. Being a single-center study is the major limitation. However, it is worthwhile to introduce the results of a single center that emergency endoscopy can be performed in a region with a high incidence of COVID-19. It can be stated that the second limitation of our study is that our unit is in a different location from the main hospital. Therefore, it may not reflect the results of an endoscopy practice in the region of intensely infected patients.

In conclusion, COVID-19 pandemic process caused extreme changes in endoscopy procedure practice and also indications. It is important to continue the use of strict PPE in this period when safe return to routine endosco- 
py is not possible in the near future. And all endoscopy units should always be accoutred for the management of emergency endoscopy procedures such as gastrointestinal bleeding. This study was approved by Sakarya University Clinical Research Ethics Committee, May 20, 2020 / E.4594. 
Sakarya Med J 2021;11(4):772-780

ACAR et al., : Emergency Endoscopy Indications in Pandemics

\section{Kaynaklar}

1. Zhu N, Zhang D, Wang W, et al. A Novel Coronavirus from Patients with Pneumonia in China, 2019. N Engl J Med 2020;382(8):727-733.

2. WHO. Coronavirus disease (COVID-2019) Situation Report 132. Geneva, Switzerland: WHO, 2020.

3. World Health Organization. WHO Director-General's opening remarks at the media briefing on COVID-19 - 11 March 2020. https://www.who.int/dg/speeches/detail/whodirectorgeneral-s-opening-remarks-at-the-media-briefing-on-covid-19---11-march-2020.

4. Daily Coronavirus Report of Turkey. Avaliable at https://covid19.saglik.gov.tr. Accessed, May 31st, 2020. Ankara,Turkey.

5. Chiu PWY, Ng SC, Inoue H, et al. Practice of endoscopy during COVID-19 pandemic: position statements of the Asian Pacific Society for Digestive Endoscopy (APSDE-COVID statements). Gut 2020;Epub ahead of print 2 April 2020.

6. Endoscopy activity and COVID-19: BSG and JAG guidance. Available at https://www.bsg. org.uk/covid-19-advice/endoscopy-activity-and-covid-19-bsg-and-jag-guidance. Accessed Apr 03, 2020

7. Soetikno R, Teoh AYB, Kaltenbach T, et al. Considerations in performing endoscopy during the COVID-19 pandemic. Gastrointest Endosc 2020 Mar 27:S0016-5107(20)34033-5

8. Center for Disease Control and Prevention. Protecting healthcare personnel. Available at: https://www.cdc.gov/hai/prevent/ppe.html. Accessed March 23, 2020.

9. Zou L, Ruan F, Huang M, et al. SARS-CoV-2 Viral Load in Upper Respiratory Specimens of Infected Patients. N Engl J Med 2020;382(12):1177-1179.

10. Pan Y, Zhang D, Yang P, Poon LLM, Wang Q. Viral load of SARS-CoV-2 in clinical samples. Lancet Infect Dis 2020;20(4):411-412

11. Gupta S, Shahidi N, Gilroy N, Rex DK, Burgess NG, Bourke MJ. Proposal for the return to routine endoscopy during the COVID-19 pandemic [published online ahead of print, 2020 Apr 28]. Gastrointest Endosc 2020;S0016-5107(20)34249-8.

12. Johnston ER, Habib-Bein N, Dueker JM, et al. Risk of bacterial exposure to the endoscopist's face during endoscopy. Gastrointest Endosc 2019;89(4):818-824.

13. Remuzzi A, Remuzzi G. COVID-19 and Italy: what next?. Lancet 2020;395(10231):12251228.

14. Repici A, Maselli R, Colombo M, et al. Coronavirus (COVID-19) outbreak: what the department of endoscopy should know [published online ahead of print, 2020 Mar 14]. Gastrointest Endosc 2020; S0016-5107(20)30245-5.
15. Han J, Wang Y, Zhu L, et al. Preventing the spread of COVID-19 in digestive endoscopy during the resuming period: meticulous execution of screening procedures [published online ahead of print, 2020 Apr 5]. Gastrointest Endosc 2020;S0016-5107(20)34133-X.

16. Castro Filho EC, Castro R, Fernandes FF, Pereira G, Perazzo H. Gastrointestinal endoscopy during the COVID-19 pandemic: an updated review of guidelines and statements from international and national societies [published online ahead of print, 2020 Apr 5]. Gastrointest Endosc 2020; S0016-5107(20)34132-8.

17. Marchese M, Capannolo A, Lombardi L, Di Carlo M, Marinangeli F, Fusco P. Use of a modified ventilation mask to avoid aerosolizing spread of droplets for short endoscopic procedures during coronavirus COVID-19 outbreak [published online ahead of print, $2020 \mathrm{Apr}$ 2]. Gastrointest Endosc 2020;S0016-5107(20)34131-6.

18. Traina M, Amata M, Granata A, Ligresti D, Gaetano B. The C-Cube: an endoscopic solution in the time of COVID-19 [published online ahead of print, 2020 Jun 19]. Endoscopy 2020;10.1055/a-1190-3462.

19. Naseer M, Lambert K, Hamed A, Ali E. Endoscopic advances in the management of non-variceal upper gastrointestinal bleeding: A review. World J Gastrointest Endosc 2020;12(1):116.

20. Fujishiro $M$, Iguchi $M$, Kakushima $N$, et al. Guidelines for endoscopic management of non-variceal upper gastrointestinal bleeding. Dig Endosc 2016;28:363-378

21. Joint GI Society-Gastroenterology professional society guidance on endoscopic procedures during the COVID-19 pandemic. 2020. Available at https://www.asge.org/home/advanced-education-training/covid-19-asge-updates for members/gastroenterology-professional-society-guidance-on-endoscopic-procedures during-the-covid-19-pandemic. Accessed March 17th, 2020

22. COVID-19: Framework for the Resumption of Endoscopic Activities from the Canadian Association of Gastroenterology. Available at https://www.cag-acg.org/images/publications/ CAG-COVID-Endo-Resumption-Final-4-28-20.pdf. Accessed April 28th, 2020

23. Lauro A, Pagano N, Impellizzeri G, Cervellera M, Tonini V. Emergency Endoscopy During the SARS-CoV-2 Pandemic in the North of Italy: Experience from St. Orsola University Hospital-Bologna. Dig Dis Sci 2020;65(6):1559-1561. 